\title{
South Africa's Quest for Democratic Education through a Language in Education Policy Perspective
}

\author{
Edmore Mutekwe' ${ }^{1}$ Mabatho Sedibe ${ }^{2}$ \\ ${ }^{1}$ Faculty of Human Sciences, Vaal University of Technology, Vanderbijlpark, South Africa \\ ${ }^{2}$ Faculty of Education, University of Johannesburg, Johannesburg, South Africa \\ Email: edmorem@vut.ac.za, sedibem@uj.ac.za
}

Received 24 April 2015; accepted 22 June 2015; published 26 June 2015

Copyright (C) 2015 by authors and Scientific Research Publishing Inc.

This work is licensed under the Creative Commons Attribution International License (CC BY). http://creativecommons.org/licenses/by/4.0/

(c) (i) Open Access

\section{Abstract}

The purpose of this paper is to examine how South Africa sought to foster democracy in education through the Language in Education Policy (LiEP) document in the post-apartheid South African education system. The paper begins with a reflective account of the background to democratic education in South Africa in the immediate post 1994 era and proceeds to examine the literature on the nature of democracy, democratic education and how the LiEP was used in the new democratic government's endeavour to foster a democratic education system in the country by elevating indigenous languages to an hypothetical same level as English and Afrikaans, which had been the dominant language of classroom instruction prior to 1994. In doing so, the paper offers a critical discussion of the LiEP itself in terms of its applicability to the South African education system. It thus explores the view that democratic education is an educational ideal in which democracy is both a goal and a method of instruction. In the paper we argue that it brings democratic values to education and can include self-determination within a community of equals, as well as such values as justice, respect and trust for all races and ethnic groups inhabiting the country (Carr \& Hartnett, 1996). In relation to the Language in Education Policy, the paper discusses how its introduction in the education system was designed to foster democracy in the curriculum by offering as its goal, learners an option to access education in the languages of their choice wherever that is reasonably possible (LiEP, 1997). This implied exalting the indigenous languages and knowledge.

\section{Keywords}

Contemporary Democracy, Classical Democracy, Indigenous Knowledge, Language in Education Policy 


\section{Introduction}

The rationale for South Africa's adoption of the LiEP was to empower learners and educators to have a choice of the language of education in schools. The assumption for this was that the learners could enjoy lessons, discover and learn to rely on their own judgments and everyday experiences. The paper argues that since education and democracy are highly correlated across countries, learners need to be made to see this relationship as a product of democracy and democratic education. It also asserts that by giving attention to local languages to be used in the education system, indigenous knowledge systems which Hountondji (2002) and Odora Hoppers argue are crucial in the transformation of societies and help to allay the fears of indigenous forms of knowledge becoming extinct due to the over-emphasis of many educational philosophies in many countries especially former colonies of Britain and other Anglophone countries to peddle Eurocentric values while denigrating indigenous systems of knowledge and education (Odora-Hoppers, 2002). Given that education and schooling teach people to interact with others and raise the benefits of civic participation, including voting and organizing, the paper argues that this fosters democracy in a nation. Democratic education thus raises the support for more democratic activities in the society and this increases the likelihood of social stability and respect for human rights as a value in education and in the wider social structure.

\section{Background}

As part of the background to this study, we adopt Jansen (2003) literature part of which reads that the language education policy that characterised apartheid schooling reflected the grotesque attempt of the white nationalist leadership to Afrikane rise South Africa. That is it sought to replace the dominance and perhaps even the hegemony of English with the dominance of the Afrikaans language and culture. That this was a futile strategy doomed to fail because of its deliberate refusal to take into account the global and domestic functions and status of English, is now perfectly obvious (Glaeser et al., 2006). The 45-years' detour in the modern history of South Africa, which is what this era represents for those who lived through it, like similar episodes in the history of all peoples, has none the less left a legacy with which we are still coming to terms and which will occupy the minds and steer the efforts of many men and women for decades to come (Jansen, 2003; Carr \& Hartnett, 1996). From the point of view of identity politics, apartheid was one of the most explicit and self-conscious modern strategies of social engineering. Mother-tongue education was legitimated in terms of the then novel position of the UNESCO scholars as the optimal language-medium policy for effective and meaningful education. By way of a reminder of the precise manner in which the matter was formulated by them, we cite the following passage (UNESCO, 2010: p. 11):

It is axiomatic that the best medium for teaching a child is his (sic) mother tongue. Psychologically, it is the system of meaningful signs that in his mind works automatically for expression and understanding. Sociologically, it is a means of identification among the members of the community to which he belongs. Educationally, he learns more quickly through it than through an unfamiliar linguistic medium. But it is not always possible to use the mother tongue in school and, even when possible, some factors may impede or condition its use.

On the surface, therefore, the official language-medium policy was in line with the most up-to-date international educational research and was approached by its founders, Eiselen and Verwoerd (Jansen, 2003), as a logical extension of the endeavour of the Afrikaner nation to other South African social groups in what was conceptualised as a multi-national state. This implied that the use of standard indigenous African languages was a cynical manoeuvre, supported disingenuously by means of scholarly evidence, to promote the retribalization or ethnicisation of the African people (Dennison, 1990). As indicated already, the history of the political resistance to segregation and by extension to apartheid was one of creating larger social identities rather than one of ethnic fragmentation (Department of Education, 2002). The architects of apartheid called on the hallowed traditions of German romantic philosophy as well as on the actual practice of European missionaries in southern Africa3 in order to create the impression that their agenda was no different from the decolonisation agenda of the British and (later) of the French, which gained momentum from about 1955 onwards. The actual results in the black schools were disastrous on numerous counts. Most of the anglophile political and cultural leadership opposed the Bantu Education policy precisely because they understood the hidden curriculum (retribalization, divideand-rule tactics) but also because they had, as indicated earlier, come to equate all worthwhile education with the English language (Guttmann, 1997).

The fact that a blatantly inferior and humiliating curriculum was being mediated through the indigenous lan- 
guages of the people constituted a mountainous dilemma for those whose first language was a Bantu language. The same applied to a lesser degree to large numbers of black Afrikaans-speaking (mostly so-called coloured) people, most of whom did not have the same passionate commitment to the language, as was the case with their white counterparts. For, as Abdurrahman and his generation of leaders had heralded, English became the language of upward mobility also for Afrikaans-speaking middle class and aspiring middle class people. Most black people came to hate Afrikaans, i.e., the standard form of the language (known as Algemeen Beskaafde Afrikaans, General Civilised Afrikaans!) as the language of the oppressor. In their eyes, Verwoerdism came to have the same enemy status as Milnerism had had for Afrikaners at the beginning of the 20th century. The last straw came in 1975-76, when the Bantu Education Ministry insisted that Afrikaans and English should be used as joint media of instruction in the senior primary and junior secondary schools for black children (Sehr, 1997).

The Soweto uprising which began on 16 June 1976 not only heralded the final rejection of Bantu Education. Retrospectively, it was clear that it also marked the beginning of the end of the apartheid experiment in social engineering (Pinar, 2003). Ethnic separation and ethnic separatism were decisively and dramatically rejected by the black people. The suspicion of all ethnically based political and educational proposals that this struggle engendered has had an enduring impact on the consciousness of most South Africans (Frazer, 1999). Today, still, one of the most difficult tasks that confront progressive educationalists in South Africa is the rehabilitation of mother tongue education not only as a valid educational strategy but as the most likely strategy to redress the educational imbalances that we have inherited from the past (Jansen, 2003). Paradoxically, the only children who enjoy all the advantages of mother tongue education from the cradle to the university and beyond are in fact L1-speakers of English and of Afrikaans (Du Plessis \& Du Plessis, 2007). An even more absurd paradox is manifest in the fact that because of six to eight years of mother tongue education, the matriculation (school-leaving) examination results of black students during what Heughs (2000: pp. 24-25) calls "the first phase” of Bantu education were incomparably better than anything before or after. In her own words:

Despite the cognitively impoverished curriculum, eight years of mother tongue instruction gave pupils the time to learn their own language through this language and to learn a second and a third language sufficiently well to make the switch in medium in the ninth year. During the first phase of Bantu Education, 1953-76, the matriculation results improved, despite the poor curriculum.... (Heughs, 2000: p. 24).

After the student uprising in 1976, the apartheid authorities were compelled to scrap the first-phase approach and had to allow a reduction of mother tongue education to the first three or four years of primary schooling. For all practical purposes, Afrikaans-medium instruction disappeared from virtually all schools for black children, even though they were still compelled to offer it as a subject at matriculation level since it was one of the two official languages of the apartheid republic. Heughs (2000: pp. 24-25) demonstrates the precipitous decline in the matriculation pass rate for black examination candidates in the ensuing 20 years. This trend has continued despite all attempts to alter it. Because the matric failure rate is the result of, among other things, the subtractive language medium policy which is itself due to the static maintenance syndrome I referred to earlier, it is one of the most devastating legacies of the apartheid era, one from which it will take decades to recover (Giroux, 1989). After years of protracted struggles and the dawn of a new democracy in South Africa, it was felt that democratic changes were inevitable and this culminated in the launch of the new language in education policy. Plans for this started in 1994 and have seen so many other changes in the education system in South Africa. It is in this light that the notion of democracy is viewed in this study. The next section thus focuses on an examination of the literature review, with a focus on, firstly the meaning and perceptions of democracy and democratic education in the South African educational context (Dahl, 1998).

\subsection{Perceptions of Democracy and Democratic Education: A Literature Review}

In discussing the meaning of democracy and the meaning of education, it is important to note that just how one approaches the concept of democracy is a matter of considerable debate. Different understandings imply contrasting educational practices. Carr and Hartnett (1996: pp. 43-45) provide us with a useful illustration in this respect. They contrast a classical conception of democracy (in which democracy is seen as a form of popular power) and a contemporary conception where democracy is viewed as a representative system of political decision-making. Table 1 illustrates and compares the above theoretical conceptions of democracy in detail as given by Carr and Hartnett (1996).

According to Carr and Hartnett (1996), a model such as this involves caricatures but the contrasts drawn can help one to approach questions around the direction and purposes of education and its relation to democratic 
Table 1. Classical and contemporary models compared.

\begin{tabular}{|c|c|c|}
\hline & Classical (direct) democracy & Contemporary (representative) democracy \\
\hline $\begin{array}{c}\text { View of } \\
\text { democracy }\end{array}$ & $\begin{array}{l}\text { Grounded in a way of life in which all can develop their } \\
\text { qualities and capacities. It envisages a society that itself } \\
\text { is intrinsically educative and in which political socialization } \\
\text { is a distinctively educative process. Democracy is a moral } \\
\text { ideal requiring expanding opportunities for direct participation. }\end{array}$ & $\begin{array}{l}\text { Results from, and reflects, the political requirements } \\
\text { of a modern market economy. Democracy is a } \\
\text { way of choosing political leaders involving, } \\
\text { for example, regular elections, representative } \\
\text { government and an independent judiciary. }\end{array}$ \\
\hline $\begin{array}{l}\text { The primary } \\
\text { aim of } \\
\text { education }\end{array}$ & $\begin{array}{l}\text { To initiate individuals into the values, attitudes } \\
\text { and modes of behaviour appropriate to } \\
\text { active participation in democratic institutions. }\end{array}$ & $\begin{array}{l}\text { To offer a minority an education appropriate } \\
\text { to future political leaders; the majority } \\
\text { an education fitted to their primary social role as pro- } \\
\text { ducers, workers and consumers. }\end{array}$ \\
\hline $\begin{array}{l}\text { Curriculum } \\
\text { content }\end{array}$ & $\begin{array}{l}\text { There is a focus on liberal education, a curriculum } \\
\text { which fosters forms of critical and explanatory knowledge } \\
\text { that allow people to interrogate social norms and to } \\
\text { reflect critically on dominant institutions and practices. }\end{array}$ & $\begin{array}{l}\text { Mass education will focus on the world of work } \\
\text { and upon those attitudes and skills, and that } \\
\text { knowledge that have some market value. }\end{array}$ \\
\hline $\begin{array}{l}\text { Typical } \\
\text { educational } \\
\text { processes }\end{array}$ & $\begin{array}{l}\text { Participatory practices that cultivate the skills } \\
\text { and attitudes that democratic deliberation require. }\end{array}$ & $\begin{array}{l}\text { Pedagogical relationships will tend } \\
\text { to be authoritarian and competition will, } \\
\text { as in society generally, play an essential role. }\end{array}$ \\
\hline $\begin{array}{c}\text { School } \\
\text { organization }\end{array}$ & $\begin{array}{l}\text { Schools are viewed as communities in which the problems } \\
\text { of communal life are resolved through collective } \\
\text { deliberation and a shared concern for the common good. }\end{array}$ & $\begin{array}{l}\text { Schools are organized around } \\
\text { a pyramidal structure with the head at its apex. }\end{array}$ \\
\hline
\end{tabular}

practices. To some extent the distinctions mirror other familiar dichotomies such as andragogy and pedagogy, and 'romantic' and 'classical' forms of education (Giroux, 1989; Lawton, 2005) although his classical position looks more like the contemporary approach discussed above. Indeed, there is some cross-over (not unexpected as someone like Rousseau has been associated to the so-called romantic position and can be linked to many of the concerns associated with direct democracy. However, the starting point and aim of education in these forms does take us along a somewhat different path.

Democracy is thus a relative term whose meanings range from people freely participating in decision making, choices of social action in society and having the ability to interact with others and raising the benefits of civic participation, including voting and organizing important social activities (Heughs, 2000). The study looks at democracy in the institution of education and discusses how the LiEP was adopted in the South African context to help develop elements of democracy in education. This implies a focus on democratic education, which is examined in the next section of this literature review. Democracy in education also involves curriculum content. The above discussed contrasting models by Carr and Hartnett also involve some very different ideas as to how the curriculum is made. The focus on deliberation and practical wisdom in the classical model will tend to link to process and praxis approaches to curriculum (Carr, 2000). For Carr, the concern with skilling in the contemporary model will lead people toward more outcome-focused models. These models can also be linked to debates around the meaning of community (Glaeser et al., 2006). The classical model may well link to appreciations that emphasize personal networks and relationships, association and communion while the contemporary model to a view of community as place (territory) and as marketized networks (Glaeser et al., 2006). According to Carr (2000), democratic Education is an educational ideal in which democracy is both a goal and a method of instruction. It brings democratic values to education and can include self-determination within a community of equals, as well as such values as justice, respect and trust. Carr points out that the history of democratic education spans from at least the 1600s. While it is associated with a number of individuals, there has been no central figure, establishment, or nation that advocated democratic education.

Locke, Dewey and Rousseau are among the proponents of democratic education. For example, in describing the teaching of children, Locke once declared that none of the things they were to learn, should ever be made a burthen to them or imposed on them as a task (Vail, 2001). According to Locke's (1962) view, it is always important to let a child enjoy the teaching and learning processes. Rousseau added his voice by arguing that pupils needed to learn willingly so as to develop their imaginative skills. For him the imaginary pupil he uses for illustration was only to learn what he could appreciate as useful not what would be thrusted upon him (Guttmann, 1989). He has to enjoy his lessons, and learn to rely on his own judgment and experience. The educators must not lay down precepts and he must let them be discovered. Rousseau also urged educators by saying let Emile 
learn science, and also let him discover it (Guttmann, 1989). He also says that as educators, we should not substitute books for personal experience because this does not teach our learners to reason freely. Instead it teaches them to use other people's reasoning and to believe a great deal but never to know anything (Held, 2005).

\subsection{The Link between Education and Democracy}

Theorists of democracy and education, for example, Dewey (1916), Glaeser, Ponzetto and Shleifer (2006), Pinar (2003) and Carr (2000) concur that across countries, education and democracy are highly inter-related especially given that schooling teaches people to interact with others and raises the benefits of civic participation, including voting and organizing. For Dewey (1916: p. 99), society which makes provision for participation in its good of all its members on equal terms and which secures flexible readjustment of its institutions through the interaction of the different forms of associated life is in so far democratic. Such a society must have a type of education which gives individuals a personal interest in social relationships and control, and the habits of the mind which secure social changes without introducing disorder.

Beyond being a good in itself, democracy can be good on instrumental grounds given the goods that flow from it. In particular, one can focus on freedoms, rights and the material benefits it affords (Dahl, 1998: p. 44) and upon the social capital it generates. These come in significant part through the educative and welfare impact of the associational life, relationships and networks linked to it (Dahl, 1998). In the battle between democracy and dictatorship, which the South African education was trying to overcome following the dawn of majority rule in 1994, democracy has a wide potential base of support but offers weak incentives to its defenders (Glaeser et al., 2006). Dictatorship provides stronger incentives to a narrower base. As education raises the benefits of civic participation, it raises the support for more democratic activities relative to dictatorships. This increases the likelihood of democratic revolutions against dictatorships and reduces that of successful anti-democratic movements.

While Locke and Rousseau were concerned only with the education of the children of the wealthy, in the 19th democracy and democratic education implies more than that to encompass liberal educational activities for all in society (Frazer, 1999). According to her schools should evolve freely from principles introduced by teachers and pupils. For her, in spite of the preponderating influence of the teacher, the pupil should always have the right not to come to school, or having come to school, not to listen to the teacher, and that teacher also has to have the right not to admit a pupil, and should be able to use all the influence he could muster to win over the community, where the children are always in the majority (Frazer, 1999).

Frazer further cites two examples of the oldest influential democratic schools in the world, Summerhill in Suffolk, England, founded in 1921 arguing that it features voluntary class attendance and a school meeting with broad powers. As a result, in the 1960s, hundreds of schools opened based on Summerhill. The other oldest democratic school cited by Frazer is that the Democratic School of Hadera, founded in Israel in 1987, which offers voluntary classes and has become the shining example to inspire the now more than twenty democratic schools in Israel. Networks supporting such democratic education schools include: The Alternative Education Resource Organization launched in 1989 to create a student-driven, learner-centered approaches to education; The annual International Democratic Education Conference, first held in 1993; The Australasian Democratic Education Community, which held its first conference in 2002; The European Democratic Education Community was founded in 2008, at the first European Democratic Education Conference (Frazer, 1999). According to Kelly (1995: p. 101), one of the major tasks that education must perform in a democratic society is the proper preparation of young citizens for the roles and responsibilities they must be ready to take on when they reach maturity. She posits that this should be viewed as the aim of education. Kelly has further argued that democratic education should foster the cultivation of the virtues, knowledge and skills necessary for economic, social, civic moral and political participation in society. Such an education system must prepare citizens to participate in consciously reproducing their society and have a conscious social reproduction role as the ideal not only of democratic education but also of democratic society (Guttmann, 1989: p. 287).

Dahl (1998) argues that for many of the ancient Greeks such participation was a good in itself. Their term for the private individual was idiotes (idiot). Such a person was literally a fool as she or he was not interested in public affairs. This grew out in part out of the recognition that humans are social beings. They are what they are because of their interactions with others. They achieve what they do because they benefit from their work. Thus, if they are all to flourish then they must recognize that they share many common interests; commit themselves to 
consider those interests (and hence the needs of others) when looking to our own; actively engage with, and seek to strengthen those situations and movements that embody democratic values and draw people together (Jeffs \& Smith, 1999: p. 38). In this view, people do not simply add together individuals and get society but instead people's lives are inter-woven together to share in a common life. As Dewey (1916: p. 87) saw it, "A democracy is more than a form of government for it is primarily a mode of associated living, a conjoint communicated experience".

In terms of the development of thinking about education for democracy in the twentieth century, it is the ideas Dewey that tower above all. His is the most significant (certainly the best read) contribution to thinking about education and democracy. He approached education as part of a broader project that encompassed an exploration of the nature of experience, of knowledge, of society, and of ethics. As such, he offers us the ideal bridge from theories of knowledge, to democratic theory and onwards to education theory (Kelly 1995: p. 87). However, consideration of his educational thinking has tended to be isolated from his social and political philosophy (Carr \& Hartnett, 1996: p. 54). No wonder it is with his conception of democracy that this literature review section began. On democracy Dewey recognized that many of the then current critiques of democracy, especially with regard to electorate's lack of knowledge, and the distance between the ideals of the classical model and the reality of government had considerable merit. As Ryan (2005: p. 25) puts it:

The problem was to make democracy in practice what it had the potential of being: not just as a political system in which governments elected by majority vote made such decisions as they could, but a society permeated by a certain kind of character, by mutual regard of all citizens for all other citizens, and by an ambition to make society both a greater unity and one that reflected the full diversity of its members' talents and aptitudes.

Dewey argued for the revitalization of public democratic life. Like Habermas in later times, he placed a great emphasis upon the role of communication in this. For Dewey, communication is the process of sharing experience till it becomes a social possession (Dewey, 1916: p.9). Through conversation about individual and group wishes, needs and prospective actions, it is possible to discover common interests and to explore the consequences of possible actions. This is what generates social consciousness or general will and creates the ability to act on collective goals (Sehr, 1997: p. 58). The process of deliberation and communication over collective goals is what Dewey (1927) viewed as a democratic public. The development of democracy was an expansion of sociability. The democratic community was in effect the community that best realized the very nature of sociability. Moral growth this involved the acquisition of a capacity for communal life as well as personal fulfilment; we become more fully who we are as we become more able to offer ourselves to others (Ryan, 1998: p. 407). A key feature of Dewey's argument was his concern for social intelligence (or social consciousness). Through its cultivation human beings began to develop the capacity collectively to enlarge their own freedom and to create a more desirable form of social life (Carr \& Hartnett, 1996: p. 59).

On education, Dewey held, amongst other things, that education is the fundamental method of social progress. It is a regulation of the process of coming to share in the social consciousness and that the adjustment of individual activity on the basis of this social consciousness is the only sure method of social reconstruction (Carr, 2000). Education must be conceived as a continuing reconstruction of experience and that the process and the goal of education are one and the same thing. This conception has due regard for both the individualistic and socialistic ideals. It is duly individual because it recognizes the formation of a certain character as the only genuine basis of right living (Department of Education, 2002). It is socialistic because it recognizes that this right character is not to be formed by merely individual precept, example or exhortation, but rather by the influence of a certain form of institutional or community life upon the individual and that the social organism through the school, may determine ethical results (Guttmann, 1989). The community's duty to education is, therefore its paramount moral duty for all citizens. If one follows this line of thinking through one can see that people learn democracy by being members of a group or community that acts democratically. In other words, it is through communication and participating in the process of deliberation that we learn to view ourselves as social beings with a concern for the common good, and responsibilities to others develop. As Dewey (1916: p. 6) expressed it, "the very process of living together educates".

The aforementioned has important implications for the way we approach schooling (or indeed any other form of education). The school must be 'primarily a mode of associated living, a conjoint communicated experience' (Dewey, 1916: p. 87). Dewey argued that much of education failed because it neglected the fundamental principle of the school as a form of community life. It conceives that school as a place where certain information is to be given, where certain lessons are to be learned, or where certain habits are to be formed. The value of these is 
conceived as lying largely in the remote future, the child must do these things for the sake of something else he is to do; they are mere preparations. As a result they do not become part of the life experience of the child and so are not truly educative (Dewey, 1940: p. 8). Conceiving the school as a community in which communication and deliberation flourishes inevitably leads us to consider the nature of relationships between student and student, students and teachers, and teacher and teacher. As Winch and Gingell (1999) note, if schools exist to promote democratic values it would appear that they need to remove authoritarian relationships. Education for democracy thus becomes education freed from authoritarian relationships (Gingell, 1999).

\section{Discussion of the LiEP}

After an extremely problematic start during the first seven years of the new Republic of South Africa, language education policy appears to be on the road towards finding a definite direction. Although the gap between the constitutional and legislative position on the one hand, and the actual practices in the classrooms and lecture halls of the country on the other hand, remains very wide and often appears to be widening, the fact that these instruments exist is of the greatest significance (Du Plessis \& Du Plessis, 2007). Drawing from Dewey views of democratic education, one can argue that his approach to democratic education has the virtue of looking to the education and or school as a community and of looking to the possibilities of associationalism. Dewey, would no doubt argue that it entails a retreat from the curricula responsibilities of the educator to those of the community and it is in this sense that policies that are all inclusive should be adopted to democratise the education system of a country like South Africa which was in 1994 emerging from apartheid policies of education (Jansen, 2003). The social background of the students and the concerns of their parents needed to be taken into account in the new education system for South Africans (Alexander, 2002). Because new communities need sympathetic builders at their heart, the new language in education policy is conceived of as a remedy to the past injustices of apartheid (Senge, 2008). The LiEP thus represented democratic space for the legal and peaceful promotion of multilingualism and for mother tongue based bilingual education in South Africa (see Appendix A). Moreover, recent developments indicate that on the part of the state, there is a definite albeit problematic commitment to the constitutional provisions on language and language education. If apartheid language policy had intentionally promoted and entrenched old and new social divisions, the language policy of the new South Africa is clearly geared to the strategy of reconciliation and nation building, which was the defining feature of former President Mandela's government. Both the constitution of the country and the language policy in education take it as their "parity of esteem". All the languages used in the country are deemed to be assets rather than problems. However, there is no doubt that in practice; the state bureaucracy as well as most of the political leadership is trapped in the language-is-a-problem paradigm. The public service is rapidly sliding in the direction of unilingualism in spite of the constitutional provision for the use of a minimum of two languages at both national and provincial levels. This has unsettled especially the Afrikaans-speaking, mainly the white Afrikaans speaking, community who fear that the hard-earned equality between Afrikaans and English is about to disappear because of the anglophile bias of the rising black middle class.

As the most organised language group, the Afrikaans speaking people are willy-nilly indicating the direction in which things could move once the racial fault line that still marks the salient division in South Africa has been addressed (Prah, 1998). That is to say, once the preoccupation of South Africans with the race question is no longer as central as it continues to be today, it is very likely that the language marker will become the next major plank for political mobilisation. In this sense, the present agitation of the Afrikaans-speaking community for the maintenance and expansion of their linguistic human rights, even if some circles are motivated by ethnicist and overtly racist, considerations, will become a model for other "linguistic communities". It is significant that the political class, specifically the black elite uses the pro- English argument precisely on the grounds that this may help to undermine the latent ethnic divisiveness of language-based mobilisation, as well as the inheritedracial identities of the apartheid and colonial past (Scholtz, 1995). Debates in the media centre on the simplistic and inarticulate belief that if only all the people of the country could rapidly acquire knowledge of the English language, all communication problems and, therefore, inter-group tensions, will disappear. Those who, inconsonance with the constitution and the evolving language legislation, stand for a multilingual (plurilingual) solution, one which includes the English language as a necessary term in any language policy equation, are still a small minority of the policy-influencing strata (Skutnabb-Kangas, 2010). For the masses of the people, the language issue remains only marginally important. Their immediate concerns are directly material insofar as they need secure jobs, housing, health and access to secondary and tertiary education for their children (Curren, 2007). 
Proponents of the LiEP (e.g. Senge, 2008) argue that it was crucial to democratise classroom instruction through the introduction of 11 languages as mediums of instruction in schools if South Africans were to access education in an effective way. Their justification for this was that democratic schools are characterized by involving students in the decision-making process that affect what and how they learn. According to Vail (2001), some democratic schools have no mandatory curriculum, considering forced learning to be undemocratic. Most democratic schools officially offer voluntary courses, and many help interested students to prepare for national examinations so they gain qualifications for further study or future employment (Senge, 2008). Some democratic schools have no official offering of courses, although courses can be offered or requested by school members (Senge, 2008).

In terms of administrative structures, democratic schools often have meetings open to all students and staff, where everyone present has a voice and sometimes an equal vote. Some include parents (Held, 2005). These school meetings can cover anything from small matters to the appointment or dismissal of staff and the creation or annulment of rules, or to general expenditure and the structure of the school day. According to Hernandez (1997) some schools all students are expected to attend these meetings, at others they are voluntary. The main school meeting may also set up sub-committees to deal with particular issues, such as conflict resolution. For the above mentioned writers this is in line with the ideals of a democratic education in society. For Senge, while types of democratic education are as numerous as types of democracy, a general definition of democratic education is an education that democratizes learning itself and by introducing 11 languages and giving them an equal status in the curriculum South Africa was indeed democratising education. In addition, Jansen (2003) also notes that the goals of democratic education vary according to the participants, the location, and access to resources. This meant that where the majority of learners spoke a particular language, then that had to be adopted as the language of classroom instruction to democratise learning (Lakoff, 1996).

Cultural theorists such as Dennison (1990) support what South Africa did to democratise education through the provision of multiple languages for instruction on the grounds that it promotes a multicultural educational approach to learning. For such theorist, democratic education is consistent with the cultural theory that learning in school must be continuous with life outside of school and that children should become active participants in the control and organization of their community (Curren, 2007). According to Senge (2008) research on hunter-gatherer societies indicates that free play and exploration are effective transmitters of the societies' culture to children and according to Dennison democratic environments are social regulators because our desire to cultivate friendships, engender respect, and maintain anatural authority' encourages us to act in socially acceptable ways (i.e. culturally informed practices of fairness, honesty, congeniality among other things).

Proponents of political theories argue that there are a variety of political components to democratic education (Jansen, 2003). Some people identify those elements as inclusivity and rights, equal participation in decision making and equal encouragement for success as politically motivated. The Institute for Democratic Education's principles of democratic education (2005) identifies several political principles: The interaction between democratic philosophy and education pluralistic education, school administration by means of democratic procedures, education based on respect for human rights, dialogic relationships, andcritical social thinking and these were taken into consideration when the LiEP was adopted for South Africa' new education in the post 1994 era. According to political theorists the type of political socialization that takes placein democratic schools is strongly related to deliberative democracy theory. Offe and Preuss (2002) two theorists of the political culture of deliberative democracies argue that in its cultural production deliberative democracy requires an open-ended and continuous learning process in which the roles of both teacher and curriculum are missing. In other words, what is to be learned is a matter that we must settle in the process of learning itself. The political culture of a deliberative democracy and its institutions, they argue, would facilitate more dialogical forms of making one's voice heard, which would be achieved within a framework of liberty, within which paternalism is replaced by autonomously adopted self-paternalism, and technocratic elitism by the competent and self-conscious judgment of citizens (UNESC, 2010). The above views are consistent with those of Guttmann who argues that in democratic education in a democratic society, there is a role for everyone in education as all children feel important and belonging. Through the introduction of the LiEP, this role was believed to have been factored in the introduction of the 11 official languages as a way of being truly inclusive in education (Alexander, 1999).

\section{Conclusion}

In concluding this broad-brush description of the relationship between democratic education and the LiEP in the 
South African context of education, except for conservative white Afrikaans-speaking people and for some $\mathrm{Zu}-$ lu-speaking people, the LiEP has helped to partly solve the language question, which once sparked controversy leading to the Soweto uprisings. Regardless of the fact that class and race issues remain more salient because of the depredations of the macro-economic policy which the present government appears to be totally committed to, and which has led to large-scale job losses, homelessness and general social diseases, the language crisis in education has been resolved although many people in society still remain clinging to certain languages as mediums of instruction for schools especially English and Afrikaans at the expense of the indigenous languages that have been given equal status with the former. This can be attributed to the economic benefits that English and Afrikaans bring to particular individual and communities. Moreover, the relapse into racial identities that has taken place because of the implementation of affirmative action and black empowerment measures in both the public and the private sectors has caused the main debates on individual and collective identities to centre on race rather than on language, but as an element of democratic education, the language issue has been rationalised although voices of dissent remain. Be that as it may, in my view, it is precisely this danger of language-based conflict within the next generation that would make the policy of promoting multilingualism and individual plurilingualism such an urgent and critically important imperative.

\section{Recommendations}

Whether or not the attainment of a non-racial, non-sexist, united democratic South Africa is possible in the medium to long term future depends largely on whether or not it will be possible to deflect on to the language domain and the friction of racial prejudice and racial and class inequalities perpetuated because of the resurgence of the discourse of language and racial identities associated with any affirmative action programme recently launched. This implies that it is important for post-apartheid South Africa to undertake an attempt to construct a language dispensation such that a spectrum of linguistic communities, a network of social communication, is created through which all the indigenous language-based identities continue to function even as they are changing, without posing a threat to the sense of national unity that is promoted in many spheres of life of the South Africa society. For this to happen, it is essential that vested economic interests be prevented from getting linked to linguistic, racial, class, religious or ethnic consciousness in any significant way. Hence also, the importance of a multi-cultural society and a multi-lingual populations especially through the institutions such as education, economy, polity or religion. To use Bourdieu's (2002) terminology, a multilingual habit us has to come into effect if the society is to be cohesive.

\section{References}

Alexander, N. (1989). Language Policy and National Unity in South Africa/Azania. Cape Town: Buchu Books.

Alexander, N. (2001). The Politics of Identity in Post-Apartheid South Africa.

Alexander, N. (2002). Linguistic Rights, Language Planning and Democracy in Post-Apartheid South Africa. In: S. Baker (Ed.), Language Policy: Lessons from Global Models. Monterey, CA: Monterey Institute of International Studies.

Bourdieu, P. (2002). Anthropologist, Social Theorist. Paris: College de France.

Carr, W. (2000). Democracy and the Curriculum. The Curriculum Journal, 7, 73-77.

Carr, W., \& Hartnett, A. (1996). Education and the Struggle for Democracy: The Politics of Educational Ideas. Buckingham: Open University Press.

Curren, R. (2007). Philosophy of Education: An Anthology. Hoboken, NJ: Blackwell Publishing.

Dahl, C. (1998). Functioning Schools in a Democratic Society. Journal of Education, 6, 33-42.

Dennison, G. (1999). The Lives of Children: The Story of the First Street School. New York: Falmer.

Department of Education (2002). Revised National Curriculum Statement Grades R-9: Overview. Pretoria: Department of Education of South Africa.

Dewey, J. (1916). My Pedagogic Creed: Education for Democracy. Chicago, IL: University of Chicago Press.

Dewey, J. (1940). Social Scientist, Progressive Education Theorist. Chicago, IL: University of Chicago Press.

Du Plessis, H., \& Du Plessis, L. (Eds.) (2007). Afrikaans en Taalpolitiek. 15 Opstelle. Pretoria: Haum.

Frazer, E. (1999). The Problems of Communitarian Politics (pp. 279). Cambridge: Cambridge University Press. http://dx.doi.org/10.1093/0198295642.001.0001 
Gingell, O. (1999). Understanding Policy and Democracy in Education. London: Longman.

Giroux, H. A. (1989). Schooling for Democracy: Critical Pedagogy in the Modern Age. New York: Routledge.

Glaeser, E., Ponzetto, G., \& Shleifer, A. (2006). Why Does Democracy Need Education? Journal of Economic Growth, 12, 77-99. http://dx.doi.org/10.1007/s10887-007-9015-1

Guttmann, A. (1987). Democratic Education and the School Curriculum. New York: Princeton University Press.

Guttmann, A. (1997). Democratic Education. Princeton, NJ: Princeton University Press.

Held, D. (1995). Democracy and the Global Order: From the Modern State to Cosmopolitan Governance. Cambridge: Polity Press.

Heughs, K. (2000). The Case against Bilingual and Multilingual Education in South Africa. Praesa Occasional Papers No. 6, Cape Town: PRAESA.

Hountondji, P. (2002). Knowledge Appropriation in a Post-Colonial Context. In C. Odora-Hoppers (Ed.), Indigenous Knowledge and the Integration of Knowledge Systems: Towards a Philosophy of Articulation (pp. 137-142). Claremont, CA: New Africa Books.

Institute for Democratic Education's Principles of Democratic Education (2005). Book Title. Pretoria: Government Printers.

Jansen, J. (2003). Curriculum and the Language Debate in the South African Education Context. South African Journal of Education, 17, 231-243.

Jeffs, B., \& Smith, M. (1999). Policy in Education. London: Verso.

Kelly, A. V. (1995). Education and Democracy: Principles and Practices. London: Paul Chapman.

Lakoff, S. (1996). Democracy: History, Theory, Practice. Boulder, CO: Westview Press.

Language in Education Policy Document (LiEP) (1997). Pretoria: Government Printers.

Locke, J. (1962). Some Thoughts Concerning Education. New York: Falmer.

Odora-Hoppers, C. (2002). Indigenous Knowledge and the Integration of Knowledge Systems: Towards a Conceptual and Methodological Framework. In C. Odora Hoppers (Ed.), Towards a Philosophy of Articulation (pp.139-143). Claremont, CA: New Africa Books.

Offe, C., \& Preuss, U. (2002). Democratic Institutions and Moral Resources: Political Theory Today. Cambridge: Polity Press.

Pinar, W. (2003). Understanding Curriculum Policy. Journal of Curriculum Studies, 5, 37-43.

Prah, K. (Ed.) (1998). Between Distinction and Extinction: The Harmonisation and Standardisation of African Languages. Johannesburg: University of the Witwatersrand Press.

Rousseau, J. (1904). Emile oul'éducation, Garnier Frères. Paris: Falmer.

Ryan, P. (2005). Challenges to Democratic Education. Journal of Philosophy of Education, 4, 57-61.

Scholtz, J. (1995). Die Afrikaner en Sy Taal 1806-1875. Cape Town: NasouBpk.

Sehr, D. T. (1997). Education for Public Policy. New York: SUNY Press.

Senge, L. (2008). The Language Question in South African Education. Journal of Education, 5, 123-131.

Skutnabb-Kangas, T. (2000). Linguistic Genocide in Education-Or Worldwide Diversity and Human Rights. Mahwah, NJ and London: Lawrence Erlbaum Associates.

United Nations Educational, Scientific and Cultural Organisation (UNESCO) (2010). The Use of Vernacular Languages in Education. Paris: UNESCO.

Vail, L. (Ed.) (2001). The Creation of Tribalism in Southern Africa. Berkeley and Los Angeles, CA: University of California Press. 